\title{
Digital re-classification of equivocal dysplastic urothelial lesions using morphologic and immunohistologic analysis
}

\author{
Authors \\ Camelia D Vrabie MD, $\mathrm{PhD}^{1}$, Marius Gangal MD, $\mathrm{PhD}, \mathrm{MBA}^{2}$ \\ 1. Senior Pathologist, Head of Pathology Department, "Sfântul Ioan" Clinical Emergency Hospital; Assist. Prof. \\ "Carol Davila" Medical University, Bucharest Romania; camianapat@yahoo.com \\ 2. Research Pathologist, Medical Data Analytics Canada (MEDACS.ca), Rigaud, J0P1P0, PQ Canada, marius.gan- \\ gal@medacs.ca.
}

\begin{abstract}
A precise diagnostic of precursor dysplastic urothelial lesions is critical for patients but it can be a challenge for pathologists. Multiple immunohistologic markers (panel) improve ambiguous diagnostics but results are subjective, with a high degree of observational variability. Our research objective was to evaluate how a classification algorithm may help morphology diagnostic. Data coming from 45 unequivocal cases of flat urothelial lesions ("training set": 20 carcinomas in situ, 8 dysplastic and 17 reactive lesions) were used as ground truth in training a random tree classification algorithm. 50 "atypia of unknown significance" diagnostics (diagnostic set) were digitally re-classified based on morphological and immunohistochemical features as possible carcinoma in situ (20), dysplastic (17) and reactive atypia cases (13). The main sorting criterium was morphologic (nuclear area). A four-markers panel was used for a precise classification ( $74 \%$ correctly classified, $93 \%$ accuracy, $76 \%$ precision, averaged $\mathrm{ROC}=0.828$ ). 3 cases were "false negative". The performance of the immunohistologic panel was evaluated based on a stain index, calculated for CD20, p53, Ki67 and observed for CD44. Within training set, the immunohistologic performance was high. In the diagnostic set both the percentage of high stain index for each marker and the percentage of cases with 2-3 strong markers were low, explaining the initial high number of equivocal cases. In conclusion, digital analysis of morphologic and immunohistologic features may bring clarification in classification of equivocal urothelial lesions. Computational pathology supports diagnostic process as it can measure features and handle data in a precise, reproducible and objective way. In our proof of concept study, a low number of cases and the (deliberate) absence of clinical data were main limitations. Validation of the method on a high number of cases, use of genomics and clinical data are essential for improving the reliability of machine learning classification
\end{abstract}

\section{Keywords:}


medRxiv preprint doi: https://doi.org/10.1101/2020.10.04.20206524; this version posted October 6, 2020. The copyright holder for this preprint (which was not certified by peer review) is the author/funder, who has granted medRxiv a license to display the preprint in perpetuity.

It is made available under a CC-BY 4.0 International license.

Computational pathology, Digital Image Analysis, Machine Learning, Immunohistologic panel makers, Urothelial dysplastic lesions

\section{Introduction}

A precise diagnostic of flat urinary bladder lesions, critical for the treatment and prognosis of patients, can be difficult even for experienced uropathologists [1]. The most recent and widely used "flat urothelial lesions" classification (World Health Organization 2004 classification, modified in 2016) positioned Carcinoma in Situ (CIS), Dysplastic Lesions (DL), Reactive Hyperplasia $(\mathrm{RH})$ and flat hyperplasia as part of a diagnostic continuum [2]. It is recommended to separate these diagnostic entities based on morphologic features [3] but a clear distinction is not always easy as bioptic tissue is scarce or fragmented, the normal urothelium histology is complex and important morphological features might be shared between normal, reactive and malign tissue [4]. CIS is described as a high-grade flat intraepithelial lesion composed of malignant cells with large hyper-chromatic nuclei (5-6x larger than a lymphocyte), serious pleomorphism and frequent mitoses, having a high propensity of developing muscle invasive cancers [5]. DL is tissue with recognizable pre-neoplastic cytological and architectural changes that are under the threshold of diagnostic of CIS [6]. RH shows smaller nuclei (2-3x the diameter of a lymphocyte nucleus), organized tissue structure, less nucleolar persistence [7] and is often associated with benign urologic pathology. A new diagnostic category, "Atypia of Unknown Significance" (AUS), sometimes named "urothelial proliferation of uncertain malignant potential" was recently added in an attempt to nest cases where a clear differentiation is difficult. AUS is still a subject of controversy and some authors recommend to avoid it as there is no robust evidence that patient outcomes are different from reactive atypia $[8,9]$. Because of overlapping morphology, a wide degree of subjectivity and inter-observational variability was reported mainly in equivocal cases $[10,11]$.

Immunohistochemistry (IHC), a histology technique that allows a precise detection of specific proteins based on the antibody-antigen reaction, may improve precision when morphologic characteristics are not enough for a clear diagnostic, when the history of the disease is unknown or there is an unusual morphologic presentation [12]. After 20 years of experience, caution is now suggested in IHC interpretation of urothelial lesions [13] as normal tissue may share some degree of staining patterns and there is no single specific/sensitive marker that can make a difference between diagnostics. A way to circumvent the IHC ambiguities is provided by the concomitant use (panels) of several IHC markers [3]. Concomitant use of 4 markers (IHC panel composed of CK20, CD44, p53, and KI-67) demonstrated a clear adjuvant value to morphology [14-16]. CD20 (cytoplasmatic) is widely recognized as the most reliable CIS associated marker [17]. KI67 (nuclear) is seen as an aggressiveness and prognostic indicator [18], usually evaluat- 
medRxiv preprint doi: https://doi.org/10.1101/2020.10.04.20206524; this version posted October 6, 2020. The copyright holder for this preprint (which was not certified by peer review) is the author/funder, who has granted medRxiv a license to display the preprint in perpetuity.

It is made available under a CC-BY 4.0 International license .

ed in connection with CD20 [19]. p53 (nuclear) is present in more than 50\% of CIS cases and is often evaluated in conjunction with CD20 as well [20]. CD44 (membranous) is considered an exclusion marker $[21,22]$. Even with the help of IHC panels, a precise diagnostic is not always possible and many cases are still classified as AUS.

Computational pathology (CP) help improving the histologic exam accuracy [23]. Digital image analysis (DIA) can assess any type of microscopic image, including IHC [24]. DIA consists of image data acquisition and ground truth generation, image analysis (object detection, segmentation and recognition) and finally statistical evaluation of digital data [25]. When data is complex or equivocal, machine learning (ML) techniques can use mathematical models (algorithms) for statistical analysis. In the case of flat urothelial lesions diagnostic, CP can use an algorithm to analyze DIA data and generate associations in an objective, measurable and reproducible way. Our research objective was to evaluate how a decision tree algorithm can reclassify the AUS diagnostics after a supervised learning instruction process [26], using both morphology and IHC (4-panel) data.

\section{Material and methods}

In this retrospective non-interventional analysis, precursor urothelial diagnostics found over a period of 3 years were re-evaluated by the principal investigator. All cases had a similar histology evaluation (Hematoxylin eosin and panel IHC) and were processed and stained using the same methodology (details concerning IHC characteristics and technique are provided in annex 1). Aside demographic info (sex and age), no other clinical information was available for this study.

Based on initial diagnostic classification, 2 datasets were created. An unequivocal "training" dataset (CIS, DL and RL) and equivocal "diagnostic" dataset (AUS). Images from both datasets were digitally analyzed in 2 steps: Data gathering (microscopic image capture, image segmentation, features measurement) was followed by data processing (data analysis, algorithm training and re-classification).

\section{Data gathering}

Microscopic images were captured using standard microscopy (objective x20 and x40, camera 12MP) and stored on a desktop computer.

1. For morphology analysis, $x 20$ images were manually segmented $[27,28]$ under 3 labels (details in annex 1, table 2a). Probability maps were evaluated with the help of an open source software [29]. Binary images were used for digital measurement of nuclear area surface and roundness (length over width ratio) (image 1). The nuclear differentiation area threshold was based on previously published data [30,31]. Structural changes of 
medRxiv preprint doi: https://doi.org/10.1101/2020.10.04.20206524; this version posted October 6, 2020. The copyright holder for this preprint (which was not certified by peer review) is the author/funder, who has granted medRxiv a license to display the preprint in perpetuity.

It is made available under a CC-BY 4.0 International license .

layers and nuclear atypia were evaluated using a semiquantitative scale (yes, no), by direct observation on binary images.

2. IHC markers evaluation was performed on $x 40$ segmented images, in 2 steps. First, cytoplasmatic and nuclear markers images were segmented (3 or 4 labels). A Region of Interest (ROI) was delineated by human pathologist in an area of maximal stain intensity. An optical density index (ODI) was determined based on ROI histogram (image 2) [32]. Using a dedicated plugin (IHC profiler), the total stained surface was measured in terms of pixel intensity of DAB stain (image 3) [33]. Finally, an IHC stain index (SI) was calculated for each IHC marker (adding only high positive and positive pixels and multiplying the sum by ODI value).

3. CD44, as membranous marker, was measured semi-quantitatively (positive, absent or patchy).

Image 1.

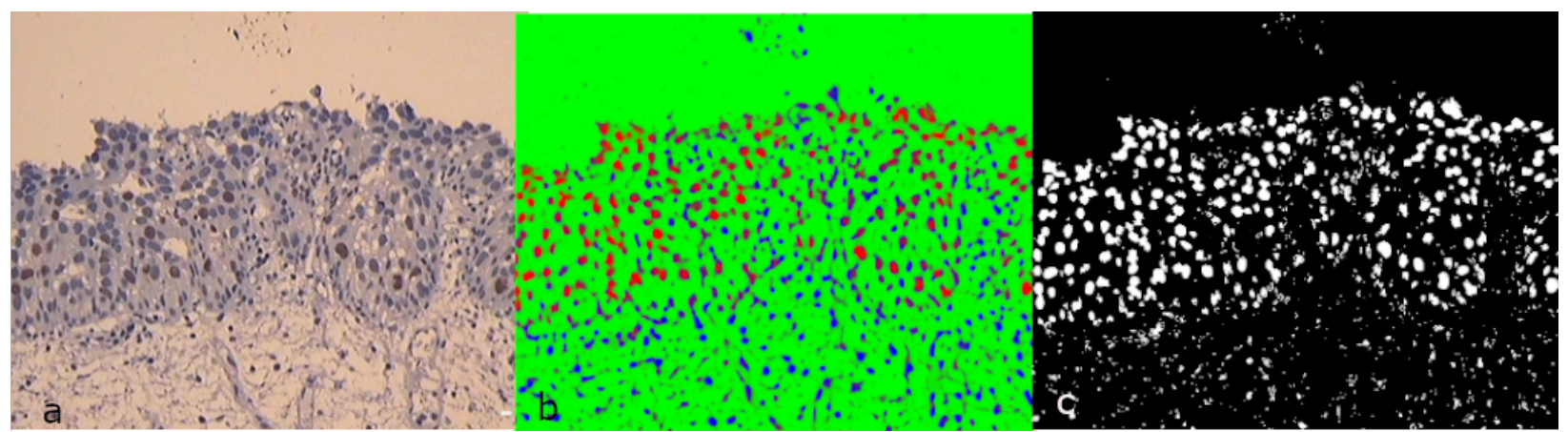

Image 1. Morphology analysis. (a) IHC image, Ki67, x20. (b) Segmented image (3 labels). (c) Binary image. Atypia $\{y e s\}$, Layer preservation $\{y e s\}$, Bar: 40 microns Image 2.

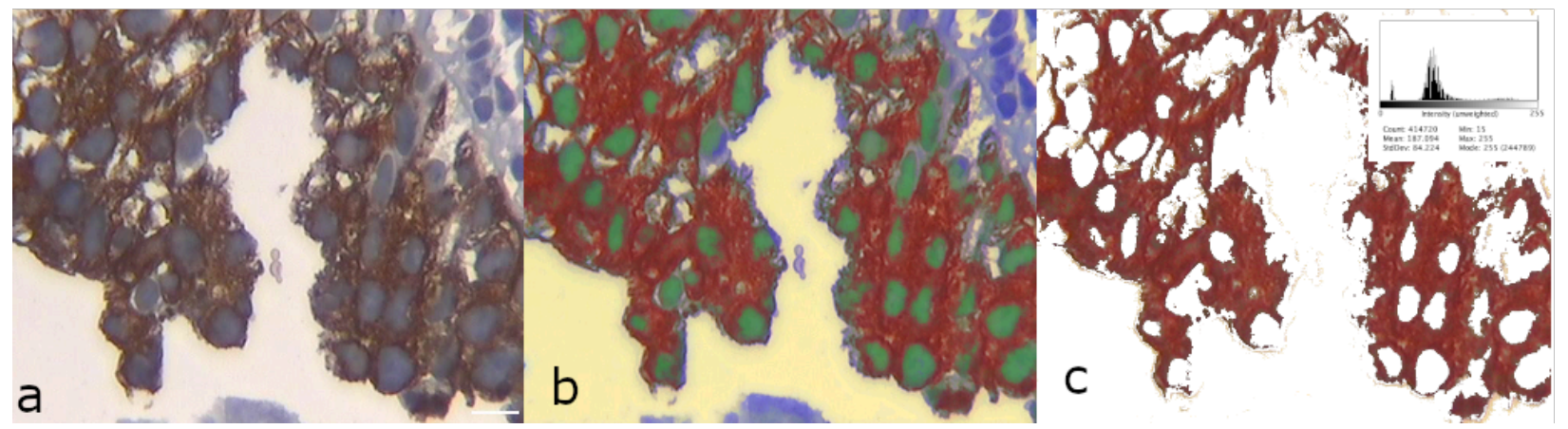

Image 2. CD20 sampling process. (a) IHC stain x40. (b) Segmented image (4 labels). (c) Intensity of staining inside ROI: histogram. Bar: 40 microns Image 3 
medRxiv preprint doi: https://doi.org/10.1101/2020.10.04.20206524; this version posted October 6, 2020. The copyright holder for this preprint (which was not certified by peer review) is the author/funder, who has granted medRxiv a license to display the preprint in perpetuity.

It is made available under a CC-BY 4.0 International license .

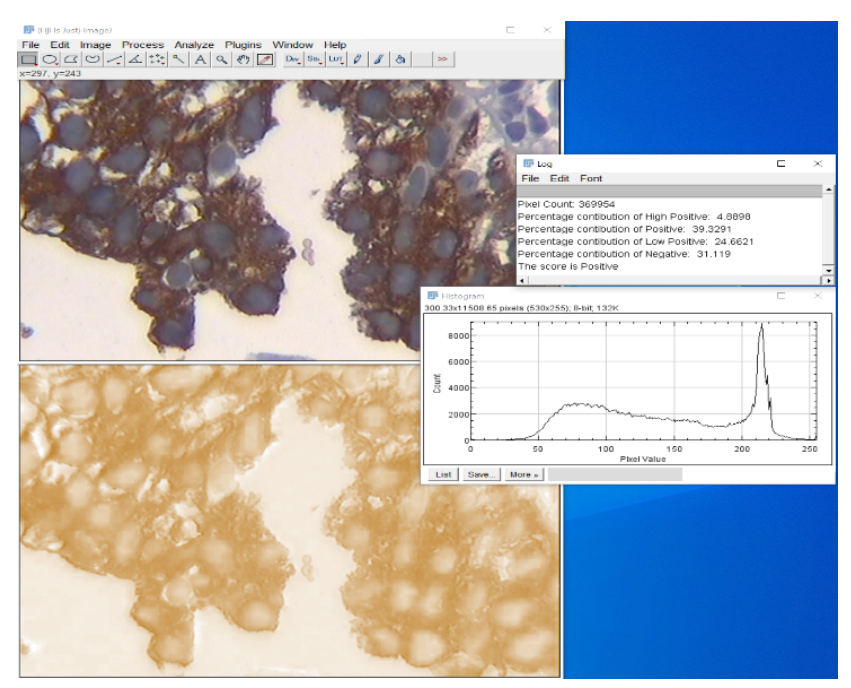

Image 3. IHC index calculation. Cytoplasmatic marker surface measurement (\%) with an open source software and a dedicated plugin (IHC profiler). Surface stained: $68.86 \%$

\section{Data processing}

A random decision tree classification algorithm was used for re-classification of all AUS cases. The "training" dataset (including all cases with a clear diagnostic of $\mathrm{CIS}, \mathrm{RH}, \mathrm{DL}$ and 5 cases of normal urothelium - 50 instances) was considered ground truth and was used for algorithm training. The "diagnostic" dataset included all cases of equivocal atypia discovered in the clinic in the same period of time (50 instances).

As both datasets were small (100 instances, 16 attributes each) we opted for an open source machine learning toolkit (WEKA) software solution that is widely accepted in bioinformatics, has a good graphical interface and requires no programming [34]. A random tree classification algorithm was selected over the classic "c4.5" as graphical representation of the decision is as intuitive but cross validating classification results were better. Datasets attributes, quantification methodology and cross-validation results are detailed in annex 1 . The structure of the random tree is presented in image 4.

Based on intensity of stain for each marker, we recorded the percentage of positive cases in each group (SI threshold for CD20 and p53 > 50\% and for Ki67 >15\%). We also counted the concomitant presence of strong stain for each marker in neoplastic against non-neoplastic groups in both training and diagnostic sets.

Image 4 


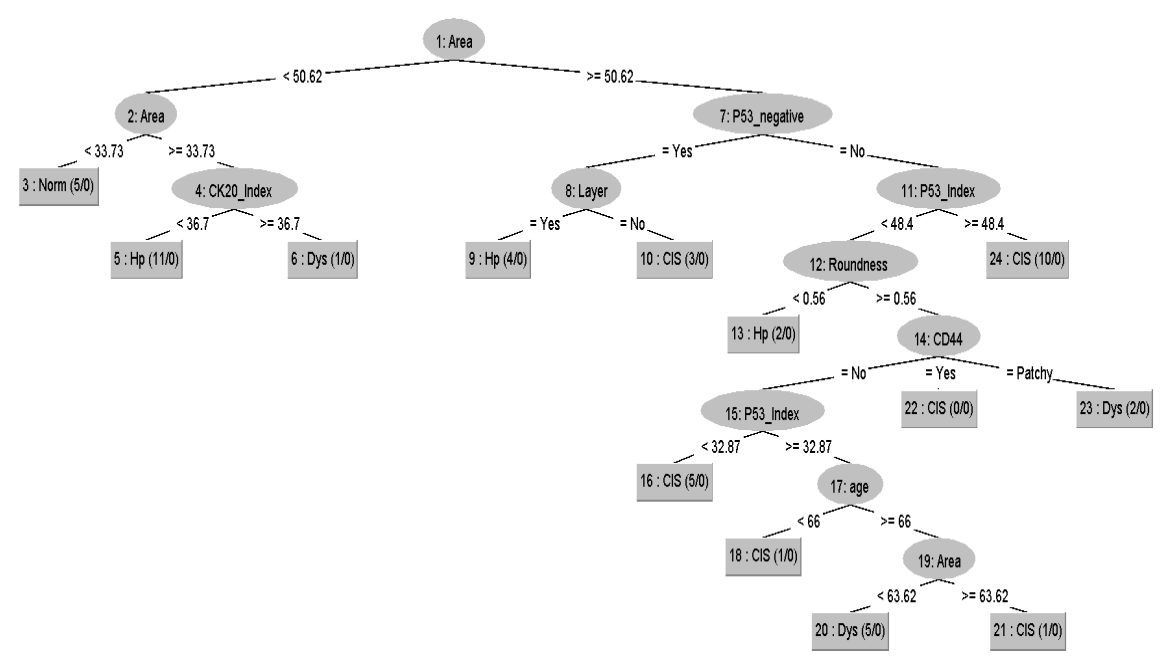

Image 4. Decision tree algorithm, training dataset, classification criteria.

\section{Statistics.}

All data was stored in a standard spreadsheet. Numerical data (age, nuclear diameter and nuclear area) was analyzed using MedCalc Statistical software (version 19.0.7, MedCalc Software bvba, Ostend, Belgium). Basic statistic results were expressed as mean \pm standard deviation. Differences between means were tested for significance with a $p$-value set at $p<0.05$.

\section{Ethics.}

Patients provided written, informed consent before surgery specifically agreeing with the processing and analyze of the pathology urothelium samples. The retrospective, non interventional IHC study protocol was approved by the hospital IRB (1123/2020).

\section{Results}

From 256 existing urinary bladder biopsies over 3 years (188 men, 68 women), 191 neoplastic cases were selected. 71 of cases received a diagnosis of T1 and 18 of T2 muscular infiltrative carcinomas. 20 cases were classified as CIS, 8 cases were DL and $17 \mathrm{HL}$ based on unequivocal morphologic and IHC features. 50 cases with an initial AUS diagnostic, were re-classified based on ground truth morphologic and IHC characteristics in $20 \mathrm{CIS}, 17 \mathrm{DL}$ and $13 \mathrm{RH}$. Results are summarized in table 1 (training dataset) and table 2 (diagnostic dataset).

Table 1 


\begin{tabular}{lllll}
\hline \multicolumn{5}{c}{ Training set } \\
\hline & CIS & DL & HL & Normal \\
\hline Nr. & 20 & 8 & 17 & 5 \\
\hline Sex & $1 \mathrm{f} / 19 \mathrm{~m}$ & $0 \mathrm{f} / 8 \mathrm{~m}$ & $3 \mathrm{f} / 14 \mathrm{~m}$ & $2 \mathrm{f} / 3 \mathrm{~m}$ \\
\hline Age & $73.75+6.7$ & $73.38+6.5$ & $67.82+8.3$ & $63.4+10.6$ \\
\hline Nuclear Area $\left(\boldsymbol{\mu}^{2}\right)$ & $59.42+4.9$ & $54.54+0.9^{*}$ & $49.09+5.4 * *$ & $32.47+1.4$ \\
\hline Layer preservation & $20 \%$ & $37.50 \%$ & $75 \%$ & $100 \%$ \\
\hline Nuclear Roundness & $0.59+0.02$ & $0.57+0.02$ & $0.54+0.02$ & $0.49+0.01$ \\
\hline Cell Atypia & $95 \%$ & $35 \%$ & $17.60 \%$ & $0 \%$ \\
\hline CK20 Superficial & $5 \%$ & $12.50 \%$ & $58.80 \%$ & $80 \%$ \\
\hline CK20 SI & $49.69+11.7$ & $44.3+13.9$ & $9.56+9.4$ & $1.24+0.43$ \\
\hline p53 Negative & $10 \%$ & $12.50 \%$ & $58.80 \%$ & $100 \%$ \\
\hline p53 SI & $37.02+17.5$ & $38.53+13.4$ & $17.00+12.6$ & $3.45+1.3$ \\
\hline Ki67 Negative & $10 \%$ & $12.50 \%$ & $53 \%$ & $80 \%$ \\
\hline Ki67 SI & $14.36+5.1$ & $10.65+3.06$ & $7.58+1.8$ & $4.52+2.9$ \\
\hline CD44 & $0 \% \mathrm{y} / 5 \% \mathrm{pt} / 95 \% \mathrm{n}$ & $0 \% / 25 \% \mathrm{pt} / 75 \% \mathrm{n}$ & $83 \% \mathrm{y} / 17 \% \mathrm{pt} / 0 \% \mathrm{n}$ & $75 \% \mathrm{y} / 25 \% \mathrm{pt} / 0 \% \mathrm{n}$ \\
\hline
\end{tabular}

Table 1. Training dataset measurement results $(* \mathrm{p}<0.05, * * \mathrm{p}<0.0001$ when compared to CIS nuclear area) (CD44: $\mathrm{y}=\mathrm{yes}, \mathrm{pt}=$ patchy, $\mathrm{n}=\mathrm{no})$

Table 2

\begin{tabular}{llll}
\hline & \multicolumn{3}{c}{ Diagnostic set } \\
\hline CIS & DL & HL \\
\hline No & 20 & 17 & 13 \\
\hline Sex & $2 \mathrm{f} / 18 \mathrm{~m}$ & $2 \mathrm{f} / 15 \mathrm{~m}$ & $0 \mathrm{f} / 13 \mathrm{~m}$ \\
\hline Nuclear Area $\left(\boldsymbol{\mu}^{2}\right)$ & $71.05+5.6$ & $72.71+7.3$ & $69.61+7.9$ \\
\hline Layer preservation & $57.95+5.02$ & $50.72+5.36^{* *}$ & $45.25+4.3^{* *}$ \\
\hline
\end{tabular}


medRxiv preprint doi: https://doi.org/10.1101/2020.10.04.20206524; this version posted October 6, 2020. The copyright holder for this preprint (which was not certified by peer review) is the author/funder, who has granted medRxiv a license to display the preprint in perpetuity.

It is made available under a CC-BY 4.0 International license .

\begin{tabular}{llll}
\hline Nuclear Roundness & $0.59+0.03$ & $0.58+0.03$ & $0.57+0.04$ \\
\hline Cell Atypia & $35 \%$ & $47 \%$ & $30.70 \%$ \\
\hline CK20 Superficial & $0 \%$ & $0 \%$ & $38.50 \%$ \\
\hline CK SI & $38.64+13.9$ & $43.16+9.37$ & $19.82+14.4$ \\
\hline p53 Negative & $35 \%$ & $11.70 \%$ & $38.50 \%$ \\
\hline p53 SI & $26.1+19.8$ & $29.04+13.1$ & $21.27+16.61$ \\
\hline Ki67 Negative & $25 \%$ & $35.25 \%$ & $30.70 \%$ \\
\hline Ki67 SI & $8.53+4.66$ & $7.35+5.04$ & $7.051+3.9$ \\
\hline CD44 & $0 \% \mathrm{y} / 0 \% \mathrm{pt} / 100 \% \mathrm{n}$ & $0 \% \mathrm{y} / 11 \% \mathrm{pt} / 89 \% \mathrm{n}$ & $0 \% \mathrm{y} / 46 \% \mathrm{pt} / 54 \% \mathrm{n}$ \\
\hline
\end{tabular}

Table 2 Diagnostic dataset. Measurement results after reclassification $(* \mathrm{p}<0.05, * * \mathrm{p}<0.0001$ when compared to CIS nuclear area) (CD44: $y=y e s, p t=$ patchy, $\mathrm{n}=\mathrm{no}$ )

\section{Discussion}

Urothelial carcinoma is the 10th most common and the second most frequent genitourinary malignancy, worldwide [35]. As urothelial carcinoma has a high recurrence rate, an early, precise differentiation of precursor neoplasms from benign reactive atypia is critical [36]. Because many flat lesions morphologic and IHC features may overlap or are shared by normal urothelium, the diagnostic is sometimes equivocal with a possible increase of medico-legal risk [37].

Our research objective was to evaluate how a machine learning algorithm can reclassify ambiguous precursor flat lesions diagnostics that were previously included under the AUS diagnostic category. A random decision tree classification algorithm was trained using data from all unequivocal flat lesions diagnosed in our unit over 3 years (20 CIS, $17 \mathrm{HL}, 8 \mathrm{DL}$ ). 5 normal urothelium IHC stained tissue were also included in the training dataset for classification purposes only. The training process used both morphologic and a "classic" 4-markers IHC panel data. Both datasets (training and a diagnostic) were digitally evaluated using open label software and affordable computational technology.

Based on classification information provided in the training dataset, the random tree algorithm reclassified the diagnostic dataset (50 AUS cases). $20 \mathrm{CIS}, 17 \mathrm{DL}$ and $13 \mathrm{HL}$ possible diagnostics were suggested.

In the classification process, as expected, the nuclear area played a central role in differentiating precursor malign from benign diagnostics. Further, layer preservation, circularity and IHC 
medRxiv preprint doi: https://doi.org/10.1101/2020.10.04.20206524; this version posted October 6, 2020. The copyright holder for this preprint (which was not certified by peer review) is the author/funder, who has granted medRxiv a license to display the preprint in perpetuity.

It is made available under a CC-BY 4.0 International license.

calculated index were used at different levels of classification. Reported differences between the nuclear area measured in diagnostic set were by $9.7 \%$ smaller than in the training set $(p=0.35)$, making human optical measurement and differentiation difficult. Similar difficulties were noticed for all other morphologic classification criteria.

The specific performance of the IHC panel was analyze based on percentage of strong SI for each marker in each set. Results are presented in table 4. In the training set, CIS/DL group had a 3-markers strong positivity in $23.75 \%$ of cases and of 2 -markers in $56.25 \%$ of cases. In the diagnostic dataset only $7.5 \%$ of cases had 3-markers and $27 \%$ a 2 -markers strong presence. For HL patients, results were negative for all inclusion markers except Ki67 in 5 cases. All cases in the diagnostic dataset were CD44 negative (13 cases were considered "patchy").

Table 4

\begin{tabular}{lllllll}
\hline & CIS train & CIS dg & DL train & DL dg & HL train & HL dg \\
\hline $\begin{array}{l}\text { CK20+ } \\
\text { (Si>50) }\end{array}$ & $70.00 \%$ & $30.00 \%$ & $50.00 \%$ & $30.00 \%$ & $0.00 \%$ & $0.00 \%$ \\
\hline $\begin{array}{l}\text { p53+ } \\
\text { (SI>50) }\end{array}$ & $45.00 \%$ & $25.00 \%$ & $0.00 \%$ & $17.00 \%$ & $0.00 \%$ & $0.00 \%$ \\
\hline $\begin{array}{l}\text { Ki67+ } \\
\text { (SI>15) }\end{array}$ & $50.00 \%$ & $35.00 \%$ & $65.00 \%$ & $17.50 \%$ & $0.00 \%$ & $5.00 \%$ \\
\hline $\begin{array}{l}\text { CD44 } \\
\text { (yes, }\end{array}$ & $0 \% / 5 \% /$ & $0 \% / 0 \% /$ & $0 \% / 25 \% /$ & $0 \% / 11 \% /$ & $83 \% / 17 \% /$ & $0 \% / 46 \% /$ \\
patchy, no) & $95 \%$ & $100 \%$ & $75 \%$ & $89 \%$ & $0 \%$ & $54 \%$
\end{tabular}

Table 4 IHC panel performance based on staining intensity for different diagnostic groups in training and diagnostic datasets (after ML re-classification)

Overall, the random tree algorithm classification had a good performance ( $74 \%$ correctly classified, $93 \%$ accuracy, $76 \%$ precision) when measured against the ground truth. The receiver operating characteristics (ROC) for CIS was 0.817 , for DL was 0.741 and for HL 0.866 . Important, only 3 cases were "false negative" (one CIS and one DL cases were classified as HL and one $\mathrm{HL}$ as DL) (confusion matrix table 3). 
Table 3

\section{Confusion matrix}

\begin{tabular}{llllll}
\hline$a$ & $b$ & $c$ & $d$ & e & Classified as: \\
\hline 14 & $1^{*}$ & 0 & 5 & 0 & $a=$ CIS \\
\hline $\mathbf{0}$ & 14 & 0 & $1^{*}$ & 2 & $b=H L$ \\
\hline 0 & 0 & 0 & 0 & 0 & $c=$ AUS \\
\hline $\mathbf{2}$ & $\mathbf{1}^{*}$ & 0 & 5 & 0 & $\mathrm{~d}=\mathrm{DL}$ \\
\hline $\mathbf{0}$ & 1 & 0 & 0 & 4 & $\mathrm{e}=$ Norm
\end{tabular}

Table 3. Confusion matrix, Random tree classification, training data set, $\left(^{*}\right)$ false negative cases meaning malign cases classified as benign or benign as malign. Mis-classification within same classes were not penalized (CIS as DL or HL as normal)

In conclusion, urothelial flat lesion classification can be a diagnostic challenge on bioptic material. Usually, a distinction between malign and benign cases is made using morphologic features and $\mathrm{IHC}$ is used mainly for confirmatory reasons. Both diagnostic methods are subjective and may have inter and intra observational variability and may generate ambiguous diagnostics. Our objective was to evaluate how CP can be used to circumvent flat lesions diagnostics uncertainty. Digital data from 45 unequivocal urothelial flat lesions data were used for training a ML algorithm (random tree). Main criteria for algorithm classification were morphological and a calculated IHC stain index coming from a classical panel of $4 \mathrm{IHC}$ markers. The performance of the classification algorithm was good: 93\% accuracy and 76\% precision, averaged ROC 0.828 . Only 3 cases were classified as "false negative". Based on this "ground truth", 50 equivocal diagnostics (AUS) were reclassified as $40 \% \mathrm{CIS}, 34 \% \mathrm{DL}$ and $26 \% \mathrm{HL}$. The IHC panel performance in classification was finally judged based on each of the 4 markers SI: in the training set, the panel performed well but in the diagnostic set, the performance was overall low.

Main limitations of this study are the low number of analysed cases (explaining the $76 \%$ precision rate), the deliberate absence of clinical data, absence of genomic information and the use of a non-customizable classification algorithm. The number of flat urothelial lesions is low and reflects the rarity of this diagnostic in everyday uro-pathology practice. The absence of clinical data is an important clinical limitation as many of flat lesions are recurrent. Long term clinical follow-up of cases, use of a molecular phenotyping information and a customized classification algorithm may further improve classification precision. 
medRxiv preprint doi: https://doi.org/10.1101/2020.10.04.20206524; this version posted October 6, 2020. The copyright holder for this preprint (which was not certified by peer review) is the author/funder, who has granted medRxiv a license to display the preprint in perpetuity.

It is made available under a CC-BY 4.0 International license .

In flat atypia equivocal cases, CP can be a support for diagnostics, as it may handle multiple data attributes in a fast, effective and precise way.

\section{References}

1. Amin MB, McKenney JK. An approach to the diagnosis of flat intraepithelial lesions of the urinary bladder using the World Health Organization/International Society of Urological Pathology consensus classification system. Adv. Anat. Pathol. 2002; 9; 222-232

2. Amin MB, Smith SC., Update for the practicing pathologist: The International Consultation On Urologic Disease-European association of urology consultation on bladder cancer, Modern Pathology (2015) 28, 612-630; doi:10.1038/modpathol.2014.158

3. Wilkerson ML., Fan Lin, The application of immunohistochemical Biomarkers in Urological Surgical Pathology, Arch Pathol Lab Med. 2014;138:16431665; doi: 10.5858/arpa.2014-0078-RA

4. McKenney, J.K., Gomez, J.A., Desai, S., Lee, M.W. and Amin, M.B. (2001) Morphologic Expressions of Urothelial Carcinoma in Situ: A Detailed Evaluation of Its Histologic Patterns with Emphasis on Carcinoma in Situ with Microinvasion. The American Journal of Surgical Pathology, 25, 356-362. http://dx.doi.org/ 10.1097/00000478-200103000-00010

5. Khani F., Robinson BD, Precursor Lesions of Urologic Malignancies, Arch Pathol Lab Med. 2017;141:1615-1632; doi: 10.5858/arpa.2016-0515-RA 6. Reuter VE, Algaba F, Amin MB et al. Non-invasive urothelial lesions. In Moch H, Humphrey PA, Ulbright TM, Reuter VE eds. WHO classification of tumours of the urinary system and male genital organs. Lyon: IARC, 2016; 99-107 7. McKenney J., Precursor lesions of the urinary bladder, Histopathology 2019, 74, 68-76. doi: 10.1111/his.13762

8. Cheng L, Cheville JC, Neumann RM, Bostwick DG. Flat intraepithelial lesions of the urinary bladder. Cancer. 2000;88(3):625-631

9. Ziemba JB, Golan R, Skokan A, et al. The clinical presentation and outcome of urothelial atypia on biopsy of the bladder. Urol Oncol. 2014;32(5): 645-647

10. Lawless ME, Tretaikova MS., Flat Urothelial Lesions With Atypia: Interobserver Concordance and Added Value of Immunohistochemical Profiling, Applied immunohistochemistry \& molecular morphology : AIMM. Volume 26; Issue 3; Pages 180-185; 2018

11. Murata S., Iseki M., et al, Molecular and Immunohistologic Analyses Cannot Reliably Solve Diagnostic Variation of Flat Intraepithelial Lesions of the Urinary 
medRxiv preprint doi: https://doi.org/10.1101/2020.10.04.20206524; this version posted October 6, 2020. The copyright holder for this preprint (which was not certified by peer review) is the author/funder, who has granted medRxiv a license to display the preprint in perpetuity.

It is made available under a CC-BY 4.0 International license .

Bladder,Am J Clin Pathol 2010;134:862-872, DOI: 10.1309 / AJCPACNUDWEN9GN4

12. Epstein JI, Reuter VE, Biopsy interpretation of the bladder Lippincot, Williams Wilkins 2010, 14-43

13. McIntire P., Khan R., Pambuccian S., Immunohistochemistry in the workup of bladder biopsies: Frequency, variation and utility of use at an academic center, Annals of Diagnostic Pathology Volume 41, August 2019, Pages 124-128, https:// doi.org/10.1016/j.anndiagpath.2019.06.002

14. McKenney JK, Desai S, Cohen C, Amin MB. Discriminatory immunohistochemical staining of urothelial carcinoma in situ and non-neoplastic urothelium: an analysis of cytokeratin 20, p53, and CD44 antigens Am J Surg Pathol. 2001 Aug;25(8):1074-8

15. Mallofre C, Castillo M, Morente V, Sole M. Immunohistochemical Expression of CK20, P53, and Ki67 as Objective Markers of Urothelial Dysplasia. Mod Pathol 2003;16(3):187-191

16. Russo S., Botti G., A useful panel in proliferative urothelial lesions: an analysis of Cytokeratin 20, p53, CD44 and Ki-67 Antigens, Pathologica 2007;99:46-49

17. Arrias-Stella III J., Shah A., et al, CK20 and p53 Immunohistochemical Staining Patterns in Urinary Bladder Specimens With Equivocal Atypia Correlation With Outcomes, Arch Pathol Lab Med. 2018;142:64-69; doi: 10.5858/ arpa.2016-0411-OA

18. Yurakh AO, Ramos D, Calabuig-Farinas S, Lopez-Guerrero JA, Rubio J, Solsona E, et al. Molecular and immunohistochemical analysis of the prognostic value of cell-cycle regulators in urothelial neoplasms of the bladder. Eur Urol 2006; 50:506-515.

19. Kunju LP., Lee CT., et al, Utility of cytokeratin 20 and Ki-67 as markers of urothelial dysplasia, Pathology International 2005; 55: 248-254, https://doi.org/ 10.1111/j.1440-1827.2005.01821.x

20. Ildiz Y., Recavarren R., et al Utility of a dual immunostain cocktail comprising of p53 and CK20 to aid in the diagnosis of non-neoplastic and neoplastic bladder biopsies Diagnostic Pathology 2009, 4:35 doi:10.1186/1746-1596-4-35

21. Toma V.., Hauri D., Focal Loss of CD44 Variant Protein Expression is Related to Recurrence in Superficial Bladder Carcinoma, American Journal of Pathology, 1999, 155, (5)

22. Lipponen P., Aaltoma S., Expression of CD44 standard and variant-v6 proteins in transitional cell bladder tumours and their relation to prognosis during a long-term follow-up $1999 \mathrm{JoP}, 1862$ doi.org/10.1002/ (SICI)1096-9896(1998100)186:2 
medRxiv preprint doi: https://doi.org/10.1101/2020.10.04.20206524; this version posted October 6, 2020. The copyright holder for this preprint (which was not certified by peer review) is the author/funder, who has granted medRxiv a license to display the preprint in perpetuity.

It is made available under a CC-BY 4.0 International license .

23. Fuchs TJ, Buhmann JM. Computational pathology: challenges and promises for tissue analysis. Comput. Med. Imaging Graph. 2011; 35(7-8):515-530.

24. Choudhury KR, Yagle KJ, et al, Robust Automated Measure of Average Antibody Staining in Immunohistochemistry Images. Journal of histochemistry and cytochemistry 2010 58: 95-107

25. Gurcan M., et al Histopatological Image Analysis, a review, IEEE Rev Biomed Eng. 2009 ; 2: 147-171. doi:10.1109/RBME.2009.2034865

26. Russell SJ, Norvig P., 2010, Artificial Intelligence: A Modern Approach, Third Edition, Prentice Hall ISBN 9780136042594.

27. Berg, S., Kutra, D., Kroeger, T. et al. ilastik: interactive machine learning for (bio)image analysis. Nat Methods 16, 1226-1232 (2019) doi:10.1038/s41592-0190582-9

28. Sommer C., Straehle C., ilastik: Interactive Learning and Segmentation kit, Heidelberg Collaboratory for Image Processing (HCI), University of Heidelberg January 24, 2011

29. Schindelin J, Arganda-Carreras I, et al Fiji: an open-source platform for biological-image analysis, Nature methods 2012 9(7): 676-682; doi: 10.1038/

nmeth.2019

30. Milord RA1, Lecksell K, Epstein JI. An objective morphologic parameter to aid in the diagnosis of flat urothelial carcinoma in situ, Hum Pathol. 2001 32(9):997-1002

31. Poropatich K, Yang JC, et al Nuclear size measurement for distinguishing urothelial carcinomas from reactive urothelium on tissue sections, Diagn Pathol. 2016 Jun 30;11(1):57. doi: 10.1186/s13000-016-0501-7

32. Ruifrok AC, Johnston DA (2001) Quantification of histochemical staining by colour deconvolution. Anal Quant Cytol Histol 23: 291-299

33. Varghese F, Bukhari AB, Malhotra R, De A (2014) IHC Profiler: An Open Source Plugin for the Quantitative Evaluation and Automated Scoring of Immunohistochemistry Images of Human Tissue Samples. PLoS ONE 9(5): e96801. doi:10.1371/journal.pone.0096801

34. Frank E., Hall M., Data mining in bioinformatics Bioinformatics, Volume 20, Issue 15, 12 October 2004, Pages 2479-2481, https://doi.org/10.1093/bioinformatics/bth261

35. GLOBOCAN v1.0, cancer incidence and mortality worldwide: IARC CancerBase No. 11. International Agency for Research on Cancer. $2012 \mathrm{http}: / / g l o b o-$ can.iarc.fr., accessed on February 2020

36. Abdel-Raheem, S., Saied, A.N., Al Shaer, R., Mustafa, O. and Ali, A.H. (2014) The Role of CK20, p53 and p63 in Differentiation of Some Urothelial Lesions of Urinary Bladder, Immunohistochemical Study. Open Journal of Pathology, 4, 181-193. http://dx.doi.org/10.4236/ojpathology.2014.44024 
37. Troxel DB., Trends in Pathology Malpractice claims, Am J Surg Path 2012 e1-e5

\section{Annex}

Table 1a

\begin{tabular}{|l|l|l|l|l|l|}
\hline AB & CLONE & DILUTION & DETECTION & $\begin{array}{l}\text { CRO- } \\
\text { MOGEN }\end{array}$ & Company \\
\hline Ki67 & MM1 & $\begin{array}{l}1: 100 / 1: 20 \\
0\end{array}$ & $\begin{array}{l}\text { MACH 4 } \\
\text { (PROBE+POLYMER) }\end{array}$ & DAB & $\begin{array}{l}\text { BIOCARE MED- } \\
\text { ICAL }\end{array}$ \\
\hline CK20 & Ks20,8 & $\begin{array}{l}1: 100 / 1: 20 \\
0\end{array}$ & MACH 2 (POLYMER) & DAB & $\begin{array}{l}\text { BIOCARE MED- } \\
\text { ICAL }\end{array}$ \\
\hline p53 & Y5 & $\begin{array}{l}1: 100 / 1: 20 \\
0\end{array}$ & MACH 2 (POLYMER) & DAB & $\begin{array}{l}\text { BIOCARE MED- } \\
\text { ICAL }\end{array}$ \\
\hline CD44 & 156-3C11 & RTU & MACH 2 (POLYMER) & DAB & $\begin{array}{l}\text { BIOCARE MED- } \\
\text { ICAL }\end{array}$ \\
\hline
\end{tabular}

Table 1a. IHC Markers Characteristics

Histologic staining was performed on $4-\mu m$-thick sections from formalin-fixed, paraffin-embedded tissue blocks.

Table 2a

\begin{tabular}{|l|l|}
\hline Segmentation $\times 20$ & $\begin{array}{l}\text { IHC atypia cells, normal cells, back- } \\
\text { ground }\end{array}$ \\
\hline Segmentation $\times 40$ & $\begin{array}{l}\text { Cytoplasm, atypia nucleus, normal nucle- } \\
\text { us, background }\end{array}$ \\
\hline
\end{tabular}

Table 2a IHC Segmentation labels

Table 3a

\begin{tabular}{|l|l|l|l|l|l|}
\hline Category & Lymphocyte & $\begin{array}{l}\text { Normal } \\
\text { Urothelium }\end{array}$ & Hyperplastic & Dysplastic & CIS \\
\hline Nucleus & 1 & $\mathrm{x} 2$ & $\mathrm{x} 2.3$ & $\mathrm{x} 2.9$ & $\mathrm{x} 4.5$ \\
\hline
\end{tabular}

Table 3a Morphologic threshold for DIA measurements in different flat urothelial lesions 


\section{Table 4a}

\begin{tabular}{|l|l|}
\hline Attribute & Quantification \\
\hline Sex & $\{\mathrm{f}, \mathrm{m}\}$ \\
\hline Age & numeric \\
\hline Area & numeric \\
\hline Structure & $\{$ Yes, No, $\}$ \\
\hline Circularity & Numeric \\
\hline Atypia & $\{0,1,2\}$ \\
\hline CK20_superficial & $\{$ Yes, No $\}$ \\
\hline CK20_index & numeric \\
\hline p53_negative & $\{$ Yes, No $\}$ \\
\hline p53_index & numeric \\
\hline Ki67_negative & $\{$ Yes, No $\}$ \\
\hline Ki67_index & numeric \\
\hline CD44 & $\{$ No, Yes, Patchy $\}$ \\
\hline Dg & $\{$ CIS, Hp, AUS, DL, Norm $\}$ \\
\hline
\end{tabular}

Table 4a Attributes and quantification methods used in algorithm training and classification datasets (CIS: carcinoma in situ, Hp: Reactive Hyperplasia, AUS: atypia of unknown significance, Dys: dysplasia, Norm: Normal urothelium)

Details of classification accuracy - training set

$===$ Detailed Accuracy By Class $===$

TP Rate FP Rate Precision Recall F-Measure MCC ROC Area PRC Area Class

$\begin{array}{lcrrccccl}0.7 \overline{0} 0 & 0.067 & 0.875 & 0.700 & 0.778 & 0.665 & 0.817 & 0.732 & \text { CIS } \\ 0.824 & 0.091 & 0.824 & 0.824 & 0.824 & 0.733 & 0.866 & 0.738 & \text { Hp } \\ ? & 0.000 & ? & ? & ? & ? & ? & ? & \text { AUS? } \\ 0.625 & 0.143 & 0.455 & 0.625 & 0.526 & 0.427 & 0.741 & 0.344 & \text { DL }\end{array}$


medRxiv preprint doi: https://doi.org/10.1101/2020.10.04.20206524; this version posted October 6, 2020. The copyright holder for this preprint (which was not certified by peer review) is the author/funder, who has granted medRxiv a license to display the preprint in perpetuity.

It is made available under a CC-BY 4.0 International license.

\author{
Weighted Avg. $\quad 0.740 \quad 0.085$ \\ $\begin{array}{cc}0.800 & 0.04 \\ 0.740 & 0.085 \\ \text { Matrix }==\end{array}$
}

$\begin{array}{cllll}\mathrm{a} & \mathrm{b} & \mathrm{c} & \mathrm{d} & \mathrm{e}<- \text { classified as } \\ 14 & 1 & 0 & 5 & 0 \mid \mathrm{a}=\mathrm{CIS} \\ 0 & 14 & 0 & 1 & 2 \mid \mathrm{b}=\mathrm{Hp} \\ 0 & 0 & 0 & 0 & 0 \mid \mathrm{c}=\text { AUS? } \\ 2 & 1 & 0 & 5 & 0 \mid \mathrm{d}=\mathrm{DL} \\ 0 & 1 & 0 & 0 & 4 \mid \mathrm{e}=\text { Norm }\end{array}$

No AUS data was provided for training in order to avoid the risk of overfitting. Neoplastic cases (CIS and DL) were considered false negative only if classified as benign. $7 \%$ of neoplastic and $5.8 \%$ of benign cases were falsely classified as negative. 